\title{
РЕЦЕНЗІї
}

\author{
Настюк В.Я., \\ доктор юридичних наук, професор, \\ заслужений діяч науки і техніки України, \\ член-кореспондент Національної академї правових наук Украӥни, \\ завідувач кафедри адміністративного права та адміністративної діяльності \\ Національного юридичного університету імені Ярослава Мудрого
}

DOI https://doi.org/10.32845/2663-5666.2020.4.20

\section{РЕЦЕНЗІЯ НА МОНОГРАФІЮ О.О. ВОРОНЯТНІКОВА «АДМІНІСТРАТИВНО-ПРАВОВЕ РЕГУЛЮВАННЯ СФЕРОЮ САНІТАРНОГО ТА ЕПДЕМІЧНОГО БЛАГОПОЛУЧЧЯ НАСЕЛЕННЯ» ${ }^{1}$}

У Видавничому центрі «Кафедра» у 2020 p. вийшла друком монографія О.О. Воронятнікова «Адміністративно-правове регулювання сферою санітарного та епідемічного благополуччя населення», яка $€$ комплексним дослідженням адміністративно-правового регулювання сферою санітарного та епідемічного благополуччя населення.

Визначаючи ступінь важливості цієї монографічної праці для сучасних вищих навчальних закладів України, передусім необхідно акцентувати увагу на тому, що санітарне та епідемічне благополуччя населення - це стан здоров'я населення та середовища життєдіяльності людини, за якого показники захворюваності перебувають на усталеному рівні для даної території, умови проживання сприятливі для населення, а параметри факторів середовища життєдіяльності знаходяться в межах, визначених санітарними нормами. Адже суспільство і держава відповідальні перед сучасним і майбутніми поколіннями за рівень здоров'я та збереження генофонду народу України, забезпечують пріоритетність охорони здоров'я в діяльності держави, поліпшення умов праці, навчання, побуту і відпочинку населення, розв'язання екологічних проблем, удосконалення медичної допомоги і запровадження здорового способу життя. На сучасному етапі розбудови українського суспільства суттєво зросла роль забезпечення умов збереження суспільного здоров'я, що можливо лише через державне управління сприяння санітарно-просвітницькій роботі, підвищення рівня санітарно-епідеміологічного нагляду, проведення профілактичних, санітарно-гігієнічних заходів. Відповідно до євроінтеграційних прагнень України державне управління санітарно-епідеміологічним наглядом як складової частини суспільної безпеки має спрямуватися на забезпечення гідного рівня санітарно-епідеміологічного благополуччя населення. Слід відзначити, що сьогоднішній вплив змін у законодавстві та невизначеність призводить до вкрай негативного результату системи протиепідемічного контролю. Актуальною залишається можливість виникнення та глобального розповсюдження небезпечних надзвичайних ситуацій на території України.

Монографічне дослідження «Адміністративно-правове регулювання сферою санітарного та епідемічного благополуччя населення», де грунтовно аналізуються вказані вище аспекти, є актуальним, очікуваним, а його результати - затребуваними наукою і практикою публічного адміністрування.

Обрана науковцем концепція дослідження дала змогу проаналізувати аспекти проблеми як порізно, так і в їх змістовно-функціональній єдності, що дало змогу отримати широкий спектр вимірів, форм прояву однієї і тієї ж самої сутності в їх спорідненості зфакторами впливу, як зовнішніми, такі внутрішніми.

У монографічному дослідженні автором обгрунтовано з точки зору науки адміністративного права методологію публічного адміністрування сферою санітарного та епідемічного благополуччя населення; досліджено генезис становлення та розвитку публічного адміністрування сферою санітарного та епідемічного благополуччя населення; поняття та особливості публічного адміністрування сферою санітарного та епідемічного благополуччя населення; принципи публічного адміністрування сферою санітарного та епідемічного благополуччя населення; державну політику щодо публічного адміністрування сферою санітарного та епідемічного благополуччя населення; поняття механізму публічного адміністрування сферою санітарного та епідемічного благополуччя населення; нормативно-правове адміністрування сферою санітарного та епідемічного благополуччя населення; повноваження та компетенцію суб'єктів публічної адміністрації як суб'єкта адміністрування сферою санітарного та епідемічного благополуччя населення; розкрито систему адміністративних заходів публічного адміністрування сферою санітарного та епідемічного благополуччя населення та систему економічних заходів публічного адміністрування сферою санітарного та епідеміч-

${ }^{1}$ Воронятніков О.О. Адміністративно-правове регулювання сферою санітарного та епідемічного благополуччя населення : монографія. Київ : Видавничий центр «Кафедра», 2020. 430 с. 
ного благополуччя населення; розкрито види профілактичних санітарних та протиепідемічних заходів, припинювальних санітарних та протиепідемічних заходів; розглянуто особливості адміністративної відповідальність за порушення норм публічного адміністрування сферою санітарного та епідемічного благополуччя населення.

Особливу увагу приділено автором дослідженню міжнародного досвіду щодо публічного адміністрування сферою санітарного та епідемічного благополуччя населення та виокремленню напрямків удосконалення публічного адміністрування сферою санітарного та епідемічного благополуччя населення.

Наукові положення, отримані автором монографічного дослідження результати можуть бути використані, поза сумнівом, у законотворчій та нормотворчій діяльності, передусім у частині внесення змін і доповнень до правових актів, які врегульовують відносини у сфері санітарного та епідемічного благополуччя населення. У ході дослідження використано офіційні статистичні дані, вітчизняні i зарубіжні наукові праці, публікації, законодавчі і підзаконні акти, фактологічні матеріали, результати соціологічних досліджень, що дає підстави відповідно до обраної парадигми наукової розвідки стверджувати про достовірність отриманих у монографії наукових положень, результатів і висновків.

Таким чином, монографія О.О. Воронятнікова «Адміністративно-правове регулювання сферою са- нітарного та епідемічного благополуччя населення» $\epsilon$ справжнім науково-теоретичним надбанням у сучасній навчальній та науковій літературі, аналогів якому не має. Саме тому розробка та видання монографії академічного рівня Воронятнікова Олександра Олександровича є важливою подією в науковому світі України.

Наведена бібліографія, iї обсяги та періодичність свідчить про те, що автор грунтував викладений матеріал на працях вчених різних країн та різних часів, що, безумовно, є свідченням додержання вченим принципу плюралізму в наукових дослідженнях.

Загалом, можна стверджувати, що рецензована монографія О.О. Воронятнікова «Адміністративно-правове регулювання сферою санітарного та епідемічного благополуччя населення» $є$ вагомим внеском у розвитку адміністративно-правової науки України. Її поява здається більш ніж своєчасною, бо саме такі монографічні праці допомагають студентам, здобувачам, аспірантам, докторантам України здобути якісні знання щодо адміністративно-правових обмежень у праві. Репрезентована наукова монографічна праця $\epsilon$, безумовно, корисним для використання в навчальному та науково-дослідному процесі у вищих навчальних закладах.

Результати дослідження можуть бути використані в подальших наукових розробках із цієї проблематики, в навчальному та науково-дослідному процесі, практичній діяльності, законодавчому процесі. 